\title{
Haemodynamic effects of acute beta-adrenergic receptor blockade in congestive cardiomyopathy
}

\author{
HAMID IKRAM, WILLIAM CHAN, SINCLAIR I. BENNETT, AND \\ PHILIP J. BONES \\ From The Department of Cardiology, The Princess Margaret Hospital, Christchurch, New Zealand
}

SUMMARY Acebutolol ('Sectral'), a cardioselective beta-blocking drug, was administered intravenously in a dose of $25 \mathrm{mg}$ to 10 patients with congestive cardiomyopathy. All of them were in a stable condition on antifailure regimens. The drug resulted in a statistically significant decline in left ventricular contractility as judged by peak left ventricular $\mathrm{dP} / \mathrm{dT}$ and the contractility index. The mean aortic blood pressure also fell. There was a significant increase in end-diastolic and end-systolic left ventricular volumes.

Mean values for heart rate, ejection fraction, left ventricular stroke work index, and cardiac output also fell, but the results were not statistically significant. Left ventricular distensibility as judged by the slope of the diastolic pressure-volume relation also improved significantly.

A reduction in myocardial energy requirements, improved compliance, and lowering of arterial pressure would be haemodynamically advantageous. However, further cardiac dilatation and reduction in contractility - the basic defects in congestive cardiomyopathy-could lead to further deterioration.

Congestive cardiomyopathy is generally regarded as a syndrome caused by diverse aetiological agents (Connolly et al., 1976). In the majority of cases the cause is unknown and current treatment grossly inadequate. Goodwin (1974) has stated that, 'at the present time the prognosis for severe congestive cardiomyopathy is so bleak and the treatment so unsatisfactory that cardiac transplantation may be considered in desperate cases'.

Waagstein et al. (1975) reported clinical improvement in 7 patients with congestive cardiomyopathy who were given oral beta-blocking drugs. These drugs were judged to have resulted in improvement on the basis of clinical signs, ergometricallymeasured exercise capacity, and non-invasive tests of cardiac function. No haemodynamic data were presented. Since a priori, beta-receptor blockade should result in worsening of cardiac function in such patients, this was a paradoxical finding. It has major implications in the therapeutic management and pathophysiology of congestive cardiomyopathies as well as the action of beta-blocking agents.

This communication reports a haemodynamic study of 10 patients with congestive cardiomyopathy in whom beta-blockade was produced by the intravenous administration of a cardioselective beta-blocker, acebutolol ('Sectral').

Received for publication 27 November 1978

\section{Subjects and methods}

Ten patients were studied, 8 men and 2 women. The clinical and electrocardiographic findings together with medication at the time of study are listed in Table 1. The diagnosis of congestive cardiomyopathy was based on the criteria outlined by Goodwin and Oakley (1972).

Coronary artery disease, pericardial, valvular, and congenital heart disease were excluded by right and left heart catheterisation, angiocardiography, and selective coronary angiography. No patient was or had been hypertensive. Secondary cardiomyopathies were excluded by appropriate tests and infiltrative cardiac muscle lesions by haemodynamic studies and endomyocardial biopsy.

All patients had had at least one episode of frank congestive cardiac failure resulting from cardiac muscle dysfunction. The first 5 patients had not been in clinical cardiac failure for at least 1 month before study. The remaining 5 patients had suffered cardiac decompensation within this period. All were on antifailure regimens at the time of study, and none was in clinical failure.

\section{(A) INVESTIGATION PROCEDURE}

All patients were studied after an overnight fast and after informed consent had been obtained. 
Table 1 Clinical data

\begin{tabular}{|c|c|c|c|c|c|c|}
\hline Case no. & Sex & Age (y) & Possible aetiology & Rhythm & QRS complex & Medication \\
\hline 1 & $\mathbf{M}$ & 52 & Alcohol & Sinus & Normal & Frusemide, digoxin, potassium \\
\hline 2 & $\mathbf{M}$ & 41 & Alcohol & Sinus & Normal & Frusemide, digoxin, potassium \\
\hline 3 & $\mathbf{M}$ & 39 & Idiopathic & Junctional & Left ventricular hypertrophy & Digoxin, frusemide, Slow $\mathrm{K}$ \\
\hline 4 & $\mathbf{M}$ & 49 & Alcohol & Sinus & Left ventricular hypertrophy & Digoxin, frusemide, potassium \\
\hline 5 & M & 32 & Alcohol & Sinus & Normal & Digoxin, frusemide, Slow K \\
\hline 6 & $M$ & 38 & Alcohol & Sinus & Normal & Digoxin, frusemide, Slow K \\
\hline 7 & $\mathrm{M}$ & 55 & Idiopathic & $\begin{array}{l}\text { Sinus with } \\
\text { ventricular } \\
\text { extrasystoles }\end{array}$ & Normal & Digoxin, frusemide, Slow K \\
\hline 8 & $\mathbf{M}$ & 29 & Viral & Sinus & Normal & Digoxin, frusemide, Slow K \\
\hline 9 & $\mathbf{F}$ & 60 & Alcohol & Sinus & Left ventricular hypertrophy & Digoxin, frusemide, Slow K \\
\hline 10 & $\mathbf{F}$ & 49 & Idiopathic & Sinus & Left bundle-branch block & Digoxin, aldactone, frusemide \\
\hline
\end{tabular}

Premedication consisted of $10 \mathrm{mg}$ intramuscular diazepam and $0.6 \mathrm{mg}$ atropine.

Selective cine coronary angiography was performed according to the technique of Judkins (1967). Right heart catheterisation was then performed by the usual techniques.

Fiftcen minutes after coronary angiography, duplicate determinations of cardiac output were made by the indicator dilution technique. Indocyanine green, $10 \mathrm{mg}$, was injected into the pulmonary artery while arterial blood was withdrawn at a constant rate through a Waters XC-301 cuvette densitometer via an aortic catheter. The densitometer was calibrated by the dynamic method (Sparling et al., 1960).

Quantitative left ventriculography was next performed in the $30^{\circ}$ right anterior oblique projection by injecting $50 \mathrm{ml}$ meglumine ('Renografin') at a rate of 10 to $15 \mathrm{ml} / \mathrm{s}$ through an 8 French 'Pigtail' catheter introduced retrogradely across the aortic valve. Acebutolol ('Sectral'), $25 \mathrm{mg}$, was then administered via the pulmonary artery catheter. Fifteen minutes later, pressure measurement, cardiac output, and left ventriculography were repeated.

After the haemodynamic study, left ventricular endomyocardial biopsy was performed by the long sheath technique (Brooksby et al., 1974) with a King's bioptome. The specimens were examined by light and electron microscopy.

\section{(B) MEASUREMENTS}

Left ventricular pressure was recorded via wellflushed catheters connected to a Bell and Howell strain gauge. The sternal angle was the zero reference. Left ventricular pressure was recorded at high speed $(200 \mathrm{~mm} / \mathrm{s})$ and high gain $(1 \mathrm{~cm}$ $=5 \mathrm{mmHg}$ ) as well as at $1 \mathrm{~cm}$ deflection equals $10 \mathrm{mmHg}$. The left ventricular pressure was digitised on a digitising table (Numonics Corp.) connected to a Wang $2200 \mathrm{~S}$ desk-top computer in order to obtain the pressure-based indices of left ventricular function.

\section{(1) Left ventricular volumes}

Left ventricular end-systolic and end-diastolic volumes were measured from the $30^{\circ}$ right anterior oblique left ventriculogram by a special-purpose calculator (Bones and Ikram, 1977).

\section{(2) Systolic ejection fraction}

This was calculated from the systolic and diastolic volumes by means of the formula:

End-diastolic volume - end-systolic volume

$$
\text { End-diastolic volume }
$$

100

\section{(3) Left ventricular peak $d P / d T$}

The peak rate of rise of left ventricular pressure was measured from the high-speed pressure tracing $(200 \mathrm{mms})$ by means of a computer programme.

(4) Left ventricular stroke work index (LVSWI) This was calculated from the formula:

LVSWI $\left(\mathrm{g} \mathrm{m} / \mathrm{m}^{2} \mathrm{BSA} /\right.$ beat $)=$ Stroke index $\times$ (mean LV systolic pressure - LV enddiastolic pressure) $\times 0.0136$

(5) Contractility index

This index of left ventricular function was calculated from the formula:

Contractility index $\left(\mathrm{g} \mathrm{m} / \mathrm{cm}^{3}\right.$ per beat $)=$ Stroke work

$$
\overline{\mathrm{LV} \text { end-diastolic volume }}
$$

\section{(6) Mean left ventricular systolic pressure}

This was obtained by digitising the area beneath the systolic portion of the left ventricular pressure tracing and converting the result to millimetres of mercury.

\section{(7) Mean aortic pressure}

This was obtained directly from the aortic pressure amplifier by electrical damping of the pressure pulse. 
(8) Left ventricular end-diastolic pressure

This was taken as the point where the left ventricular pressure pulse began its rapid upstroke on the high gain left ventricular pressure recording.

\section{(9) Left ventricular compliance}

In this study it was assumed that the left ventricular pressure-volume curve was exponential (Noble et al., 1969; Gaasch et al., 1972) and conformed to: $\mathbf{P}=$ be $^{\mathrm{kV}}$. This can also be written $\mathrm{k}=(\ln \mathrm{P}-\ln \mathrm{b}) /$ $V$. In the formula $P$ is the left ventricular enddiastolic pressure, $\mathrm{V}$ is the end-diastolic volume $\left(\mathrm{ml} / \mathrm{m}^{2}\right), \quad b$ is the extrapolated left ventricular pressure at zero $\mathrm{V}$, is the slope of the $\log \mathrm{P}-\mathrm{V}$ relation, and $e$ is the base of the natural logarithm. The constant $b$ cannot be measured easily in humans so it was assumed to be the same as that derived from animal studies, that is $0.43 \mathrm{mmHg}$.
$K$ (stiffness constant) is the slope of the $P-V$ function and is independent of pressure as well as of large changes in ventricular size. It is slightly affected by changes in ventricular geometry (Diamond et al., 1971). Compliance at enddiastole was calculated from the formula

$$
\mathrm{dV} / \mathrm{VdP}\left(\mathrm{mmHg}^{-1}\right)=\mathrm{dV} / \mathrm{dP} \times 1 / \mathrm{V} .
$$

Statistical analysis was performed by Student's paired $t$ test.

\section{Results}

The results are detailed in Tables 2 and 3.

\section{(1) HEART RATE}

There was an overall fall of 8 per cent in heart rate after acebutolol. This was not statistically significant.

Table 2 Haemodynamic data before and after acebutolol

\begin{tabular}{|c|c|c|c|c|c|c|c|c|c|c|c|c|c|c|c|c|}
\hline \multirow[t]{2}{*}{$\begin{array}{l}\text { Case } \\
\text { no. }\end{array}$} & \multicolumn{2}{|c|}{$\begin{array}{l}\text { Heart ratel } \\
\text { min }\end{array}$} & \multicolumn{2}{|c|}{$\begin{array}{l}\text { Mean aortic } \\
\text { pressure } \\
(\mathrm{mm} H \mathrm{~g})\end{array}$} & \multicolumn{2}{|c|}{$\begin{array}{l}\text { Mean left } \\
\text { ventricular } \\
\text { systolic } \\
\text { pressure } \\
(\mathrm{mm} H \mathrm{~g})\end{array}$} & \multicolumn{2}{|c|}{$\begin{array}{l}\text { End-diastolic } \\
\text { pressure } \\
(\mathrm{mmHg})\end{array}$} & \multicolumn{2}{|c|}{$\begin{array}{l}\text { Cardiac } \\
\text { index }\end{array}$} & \multicolumn{2}{|c|}{$\begin{array}{l}\text { End-systolic } \\
\text { volume } \\
\left(\mathrm{ml} / \mathrm{m}^{2}\right)\end{array}$} & \multicolumn{2}{|c|}{$\begin{array}{l}\text { End-diastolic } \\
\text { volume } \\
\left(\mathrm{ml} / \mathrm{m}^{2}\right)\end{array}$} & \multicolumn{2}{|c|}{$\begin{array}{l}\text { Ejection } \\
\text { fraction } \\
(\%)\end{array}$} \\
\hline & Pre & Post & Pre & Post & Pre & Post & Pre & Post & Pre & Post & Pre & Post & Pre & Post & Pre & Post \\
\hline $\begin{array}{r}1 \\
2 \\
3 \\
4 \\
5 \\
6 \\
7 \\
8 \\
9 \\
10\end{array}$ & $\begin{array}{r}98 \\
73 \\
101 \\
74 \\
80 \\
96 \\
112 \\
81 \\
78 \\
90\end{array}$ & $\begin{array}{r}88 \\
75 \\
110 \\
72 \\
85 \\
92 \\
70 \\
83 \\
77 \\
62\end{array}$ & $\begin{array}{l}72 \\
70 \\
93 \\
75 \\
97 \\
79 \\
85 \\
74 \\
88 \\
91\end{array}$ & $\begin{array}{r}64 \\
66 \\
90 \\
68 \\
100 \\
73 \\
76 \\
67 \\
79 \\
81\end{array}$ & $\begin{array}{r}89 \\
78 \\
93 \\
142 \\
128 \\
97 \\
109 \\
81 \\
97 \\
119\end{array}$ & $\begin{array}{r}74 \\
70 \\
102 \\
140 \\
115 \\
92 \\
70 \\
68 \\
85 \\
94\end{array}$ & $\begin{array}{r}15 \\
8 \\
6 \\
35 \\
26 \\
23 \\
23 \\
18 \\
35 \\
20\end{array}$ & $\begin{array}{r}14 \\
11 \\
8 \\
32 \\
12 \\
23 \\
24 \\
16 \\
24 \\
8\end{array}$ & $\begin{array}{l}3.05 \\
2.39 \\
4.04 \\
3.8 \\
3.04 \\
2.37 \\
2.14 \\
1.74 \\
1.32 \\
2.34\end{array}$ & $\begin{array}{l}2.08 \\
1.6 \\
4.79 \\
2.6 \\
3.06 \\
1.99 \\
1.65 \\
1.90 \\
1.23 \\
2.11\end{array}$ & $\begin{array}{r}61 \\
56 \\
33 \\
64 \\
66 \\
157 \\
147 \\
95 \\
107 \\
154\end{array}$ & $\begin{array}{c}103 \\
68 \\
41 \\
75 \\
78 \\
152 \\
163 \\
106 \\
130 \\
151\end{array}$ & $\begin{array}{r}126 \\
116 \\
64 \\
126 \\
138 \\
217 \\
211 \\
128 \\
168 \\
216\end{array}$ & $\begin{array}{r}141 \\
124 \\
60 \\
138 \\
132 \\
227 \\
207 \\
154 \\
203 \\
246\end{array}$ & $\begin{array}{l}51 \\
52 \\
49 \\
49 \\
52 \\
28 \\
30 \\
26 \\
36 \\
29\end{array}$ & $\begin{array}{l}27 \\
45 \\
33 \\
47 \\
41 \\
33 \\
21 \\
31 \\
36 \\
39\end{array}$ \\
\hline $\begin{array}{l}\text { Mean } \\
\text { SD } \\
\mathbf{P} \\
\text { Norma } \\
\text { Referer }\end{array}$ & $\begin{array}{l}88 \cdot 3 \\
13 \cdot 1 \\
\text { lues }\end{array}$ & $\begin{array}{l}81.4 \\
13.5 \\
\text { NS } \\
- \\
-\end{array}$ & $\begin{array}{c}82.4 \\
9.64\end{array}$ & $\begin{array}{l}76.4 \\
11.6 \\
0.001 \\
- \\
-\end{array}$ & $\begin{array}{r}103.3 \\
20.9\end{array}$ & $\begin{array}{l}91 \cdot 1 \\
23.4 \\
0.05 \\
- \\
-\end{array}$ & $\begin{array}{r}20.9 \\
9.8\end{array}$ & $\begin{array}{l}17 \cdot 2 \\
8 \cdot 1 \\
\text { NS } \\
9 \pm 4 \\
-\end{array}$ & $\begin{array}{l}2.623 \\
0.86\end{array}$ & $\begin{array}{l}2 \cdot 30 \\
1 \cdot 01 \\
\text { NS } \\
\star\end{array}$ & $\begin{array}{l}93.9 \\
45.3\end{array}$ & $\begin{array}{l}106.4 \\
41.5 \\
0.005 \\
24 \pm 10 \\
t\end{array}$ & $\begin{array}{r}150 \cdot 8 \\
50.9\end{array}$ & $\begin{array}{l}163.3 \\
56.5 \\
0.01 \\
70 \pm 12 \\
t\end{array}$ & $\begin{array}{l}40 \cdot 2 \\
11 \cdot 3\end{array}$ & $\begin{array}{l}35 \cdot 3 \\
8 \cdot 03 \\
N S \\
67 \pm 8 \\
t\end{array}$ \\
\hline
\end{tabular}

*Barratt-Boyes and Wood (1958). †Kennedy et al. (1966).

Table 3 Haemodynamic data before and after acebutolol

\begin{tabular}{|c|c|c|c|c|c|c|c|c|c|c|c|c|c|}
\hline $\begin{array}{l}\text { Case } \\
\text { no. }\end{array}$ & \multicolumn{2}{|c|}{$\begin{array}{l}\text { Stroke volume } \\
\text { index } \\
\left.\text { (ml/beat per } m^{2}\right) \\
\text { Pre Post }\end{array}$} & & \multicolumn{2}{|c|}{$\begin{array}{l}\text { Left ventricular } \\
\max d P / d T \\
(\mathrm{~mm} H \mathrm{~g} / \mathrm{s})\end{array}$} & \multicolumn{2}{|c|}{$\begin{array}{l}\text { Stiffness constant } \\
(K)\end{array}$} & \multicolumn{2}{|c|}{$\begin{array}{l}\text { Stroke work index } \\
\left(g \mathrm{~m} / \text { beat per } \mathrm{m}^{2}\right)\end{array}$} & \multicolumn{2}{|c|}{$\begin{array}{l}\text { Contractility index } \\
\left(\mathrm{g} \mathrm{m} / \text { beat per } \mathrm{cm}^{3}\right)\end{array}$} & \multicolumn{2}{|c|}{$\begin{array}{l}\text { Compliance } \\
\left(m m H^{-1}\right)\end{array}$} \\
\hline $\begin{array}{r}1 \\
2 \\
3 \\
4 \\
5 \\
6 \\
7 \\
8 \\
9 \\
10\end{array}$ & $\begin{array}{l}31 \cdot 2 \\
33 \cdot 7 \\
41 \cdot 3 \\
51 \cdot 9 \\
38 \cdot 0 \\
25 \cdot 7 \\
19 \cdot 1 \\
21 \cdot 5 \\
18 \cdot 0 \\
26 \cdot 0\end{array}$ & $\begin{array}{l}23 \cdot 6 \\
22 \cdot 3 \\
40 \cdot 6 \\
36 \cdot 2 \\
36 \cdot 0 \\
22 \cdot 7 \\
23 \cdot 6 \\
22 \cdot 9 \\
13 \cdot 7 \\
33.7\end{array}$ & & $\begin{array}{r}1346 \\
867 \\
1494 \\
1057 \\
1671 \\
1510 \\
1546 \\
1190 \\
950 \\
1119\end{array}$ & $\begin{array}{r}900 \\
1021 \\
1567 \\
1083 \\
1473 \\
856 \\
710 \\
713 \\
1112 \\
1078\end{array}$ & $\begin{array}{l}0.028 \\
0.026 \\
0.043 \\
0.034 \\
0.030 \\
0.018 \\
0.018 \\
0.028 \\
0.026 \\
0.017\end{array}$ & $\begin{array}{l}0.025 \\
0.026 \\
0.048 \\
0.031 \\
0.025 \\
0.017 \\
0.019 \\
0.023 \\
0.020 \\
0.012\end{array}$ & $\begin{array}{l}31 \cdot 5 \\
31 \cdot 2 \\
66 \cdot 3 \\
76 \cdot 3 \\
51 \cdot 0 \\
24 \cdot 7 \\
22 \cdot 5 \\
16 \cdot 3 \\
13 \cdot 7 \\
34 \cdot 7\end{array}$ & $\begin{array}{l}19 \cdot 2 \\
17 \cdot 5 \\
55 \cdot 4 \\
52 \cdot 5 \\
54 \cdot 2 \\
20 \cdot 5 \\
12 \cdot 0 \\
16 \cdot 4 \\
13 \cdot 2 \\
37 \cdot 0\end{array}$ & $\begin{array}{l}0.25 \\
0.27 \\
1.03 \\
0.64 \\
0.37 \\
0.11 \\
0.11 \\
0.13 \\
0.08 \\
0.16\end{array}$ & $\begin{array}{l}0.14 \\
0.14 \\
0.92 \\
0.38 \\
0.41 \\
0.09 \\
0.06 \\
0.11 \\
0.06 \\
0.15\end{array}$ & $\begin{array}{l}0.0187 \\
0.0365 \\
0.0632 \\
0.0089 \\
0.0093 \\
0.0109 \\
0.0109 \\
0.0172 \\
0.0064 \\
0.0130\end{array}$ & $\begin{array}{l}0.0187 \\
0.0280 \\
0.0427 \\
0.0022 \\
0.025 \\
0.0109 \\
0.0098 \\
0.0172 \\
0.0103 \\
0.0427\end{array}$ \\
\hline $\begin{array}{l}\text { Mean } \\
\text { SD } \\
\mathbf{P} \\
\text { Norm } \\
\text { Refere }\end{array}$ & $\begin{array}{r}30 \cdot 6 \\
10 \cdot 8 \\
\text { lues }\end{array}$ & $\begin{array}{l}27 \cdot 5 \\
8 \cdot 49 \\
\text { NS } \\
- \\
-\end{array}$ & & $\begin{array}{l}1275 \\
276 \cdot 8\end{array}$ & $\begin{array}{c}1151 \\
413 \cdot 3 \\
0.02 \\
1600 \pm 400 \\
-\end{array}$ & $\begin{array}{l}0.027 \\
0.0080\end{array}$ & $\begin{array}{l}0.025 \\
0.0098 \\
0.05 \\
0.047 \pm 0.02 \\
\star\end{array}$ & $\begin{array}{l}36 \cdot 8 \\
21 \cdot 08\end{array}$ & $\begin{array}{c}29 \cdot 8 \\
18 \cdot 1 \\
N S \\
69 \pm 25 \\
t\end{array}$ & $\begin{array}{l}0.315 \\
0.302\end{array}$ & $\begin{array}{c}0.264 \\
0.267 \\
0.05 \\
>0.5 \\
\ddagger\end{array}$ & $\begin{array}{l}0.019 \\
0.018\end{array}$ & $\begin{array}{c}0.021 \\
0.013 \\
\text { NS } \\
05 \pm 0.02 \\
\star\end{array}$ \\
\hline
\end{tabular}

*Gaasch et al. (1972). †Snell and Luchsinger (1965). ¥Miller et al. (1965). 
(2) EJECTION FRACTION

The ejection fraction fell by 8 per cent, this change again being statistically insignificant.

(3) END-DIASTOLIC VOLUME

There was a significant increase in end-diastolic volume of 10 per cent $(P<0.01)$.

(4) END-SYSTOLIC VOLUME

This was increased by 21 per cent which was highly significant $(P<0.005)$.

(5) MAXIMUM RATE OF LEFT VENTRICULAR PRESSURE RISE

This also fell significantly. The magnitude of the fall being 19 per cent $(P<0.02)$.

(6) MEAN LEFT VENTRICULAR SYSTOLIC PRESSURE

There was a fall of 10 per cent in this variable $(\mathrm{P}<0.05)$.

(7) LEFT VENTRICULAR STROKE WORK INDEX This index of left ventricular performance fell by 13 per cent but the magnitude of the fall was not significant.

(8) CONTRACTILITY INDEX

This index normalises the stroke work for change in ventricular volume. This fell significantly by 21 per cent $(P<0.05)$ indicating significantly less work was performed per unit left ventricular volume.

(9) END-DIASTOLIC PRESSURE

This showed a small fall which was not statistically significant.

(10) CARDIAC INDEX

There was a 10 per cent fall in cardiac index. This was not significant.

(11) STROKE VOLUME INDEX

This also fell insignificantly $(10 \%)$.

(12) MEAN CENTRAL AORTIC PRESSURE

There was a highly significant fall in mean aortic pressure of 7 per cent $(P<0.001)$.

(13) STIFFNESS CONSTANT

This decreased by 10 per cent indicating decrease in stiffness. The result was significant at the 5 per cent level.

(14) LEFT VENTRICULAR COMPLIANCE This measure of left ventricular compliance also altered in the direction of increased compliance (11\%) but the result did not achieve significant levels.

\section{Discussion}

Acebutolol is a cardioselective beta-blocking drug with one-quarter to one-seventh the beta-blocking potency of propranolol (Lewis et al., 1973). It also possesses intrinsic sympathomimetic activity. Hence it has similar pharmacological properties to alprenolol and practolol which were used by Waagstein et al. (1975) in their oral treatment of patients with congestive cardiomyopathy.

The dose of $25 \mathrm{mg}$ was chosen because the haemodynamic response to $30 \mathrm{mg}$ intravenously has been reported in normal subjects (Lewis et al., 1973). Left ventricular contractility as judged by peak $\mathrm{dP} / \mathrm{dT}$ and $\mathrm{V}$ max fell by 16 per cent and 14 per cent, respectively. There was little change in mean arterial pressure ( $2 \%$ fall) or left ventricular end-diastolic pressure (5\% rise).

Waagstein et al. (1975) attributed much of the observed therapeutic benefit in their patients to a reduction of heart rate. They postulated that since left ventricular external work is equivalent to the product of heart rate and systolic blood pressure, a reduction in the former would reduce work load and also permit better diastolic filling.

The mean pretreatment heart rate was higher and the magnitude of the fall after treatment $(19 \%)$ was greater than in our series $(8 \%)$. This may be because their patients were deteriorating whereas ours were clinically stable. Premedication with atropine in our cases may also have contributed to the smaller fall in rate. None the less, beta-blockade results in some reduction in cardiac rate which may be beneficial.

The majority of our patients showed an increase in end-diastolic and end-systolic left ventricular volumes after beta-blockade, with a small reduction in systolic ejection fraction. These changes indicate a negative inotropic effect. They are in contrast to the observations of Waagstein et al. (1975) who noted a progressive reduction in radiographic cardiac size after beta-blockade. There are several inherent problems in the measurement of cardiac volumes by angiography, and they are accentuated in these patients with their very large and poorly contracting left ventricular silhouettes. However, non-angiographic radiological methods have also shown an increase in the heart size of normal subjects after beta-blockade (Chamberlain, 1966).

Stroke volume increased in 3 patients and fell in 7 , the overall change being a fall of 3 per cent. This was not statistically significant nor was the 
10 per cent fall in cardiac index. Waagstein et al. (1975) speculated that a reduction in tachycardia would allow better diastolic filling and thus increase stroke volume. Our results indicate that this does happen in some patients, but the increase is small and unpredictable.

Myocardial contractility as judged by peak rate of rise of left ventricular pressure fell significantly in all but 2 cases. This is in keeping with the well-known effects of beta-blocking drugs. Left ventricular stroke work showed some fall with betablockade, but the results were not statistically significant. Stroke work per unit of end-diastolic volume ('contractility index'), another measure of myocardial contractility, showed a significant fall. These findings indicate a decline in contractility. Since cardiomyopathic patients already suffer from impaired contractility, it is arguable that betablockade would be harmful. On the other hand, since contractility is a major determinant of myocardial energy requirements, a decrease would reduce the heart's energy needs.

The systemic arterial blood pressure fell in all patients, the fall being highly significant statistically. Waagstein et al. (1975) also reported a fall in blood pressure 3 to 7 days after oral beta-blockade. Since systolic arterial pressure is a determinant of myocardial energy needs, a fall would diminish the work load of the left ventricle.

Left ventricular compliance has been shown to be reduced in patients with congestive cardiomyopathy (Gaasch et al., 1972). The effect of betablockade on compliance in these patients has not been previously reported. Though there are several practical and theoretical problems in the measurement of compliance, this study suggests that betablockade may improve compliance. This tends to improve filling and reduce end-diastolic pressure.

Waagstein et al. (1975) quote the prolonged bedrest regimen of McDonald et al. (1972) in support of their hypothesis that reduction of myocardial work is of therapeutic benefit. These authors put patients with congestive cardiomyopathy to bed for periods ranging from an average of 73 to 239 days. They observed relief of symptoms and a reduction in heart size which was proportional to the duration and degree of bed rest. Our study confirms that beta-blockade decreases most of the determinants of cardiac work, that is rate, systolic blood pressure, and contractility. However, in our experience, these theoretically beneficial changes are accompanied by further cardiac dilatation and decline in contractility -an apparent worsening of the basic defects in congestive cardiomyopathy.

The authors acknowledge the advice of Dr R. B. Khambatta.

\section{References}

Barratt-Boyes, B. G., and Wood, E. H. (1958). Cardiac output and related measurements and pressure values in the right heart and associated vessels together with an analysis of the hemodynamic response to the inhalation of high oxygen mixtures in healthy subjects. Fournal of Laboratory and Clinical Medicine, 51, 72-90.

Bones, P. J., and Ikram, H. (1977). A method of left ventricular ejection fraction estimation from cine angiocardiograms employing a special-purpose calculator. Cardiovascular Research, 11, 470-474.

Brooksby, I. A. B., Jenkins, B. S., Coltart, D. J., WebbPeploe, M. M., and Davies, M. J. (1974). Left ventricular endomyocardial biopsy. Lancet, 2, 1222-1225.

Chamberlain, D. A. (1966). Effect of beta adrenergic blockade on heart size. American fournal of Cardiology, 18, 321-325.

Connolly, M. E., Kersting, F., and Dollery, C. T. (1976). The clinical pharmacology of beta-adrenoceptor-blocking drugs. Progress in Cardiovascular Diseases, 19, 203-234.

Diamond, G., Forrester, J. S., Hargis, J., Parmley, W. W., Danzig, R., and Swan, H. J. C. (1971). Diastolic pressure volume relationships in the canine left ventricle. Circulation Research, 29, 267-275.

Gaasch, W. H., Battle, W. E., Oboler, A. A., Banas, J. S., jun, and Levine, H. J. (1972). Left ventricular stress and compliance in man. Circulation, 45, 746-762.

Goodwin, J. F. (1974). Prospects and predictions for the cardiomyopathies. Circulation, 50, 210-219.

Goodwin, J. F., and Oakley, C. M. (1972). The cardiomyopathies. British Heart fournal, 34, 545-552.

Judkins, M. P. (1967). Selective coronary arteriography. I. A percutaneous transfemoral technic. Radiology, 89, 815-824.

Kennedy, J. W., Baxley, W. A., Figley, M. M., Dodge, H. T., and Blackmon, J. R. (1966). Quantitative angiocardiography. I. The normal left ventricle in man. Circulation, 34, 272278.

Lewis, B. S., Bakst, A., Mitha, A. S., Purdon, K., and Gotsman, M. S. (1973). Haemodynamic effects of a new beta-blocking agent 'Sectral' (M. \& B. 17803A). British Heart fournal, 35, 743-751.

McDonald, C. D., Burch, G. E., and Walsh, J. J. (1972). Prolonged bed rest in the treatment of idiopathic cardiomyopathy. American fournal of Medicine, 52, 41-50.

Miller, G. A. H., Kirklin, J. W., and Swan, H. J. C. (1965). Myocardial function and left ventricular volumes in acquired valvular insufficiency. Circulation, 31, 374-384.

Noble, M. I. M., Milne, E. N. C., Goerke, R. J., Carlsson, E., Domenech, R. J., Saunders, K. B., and Hoffman, J. I. E. (1969). Left ventricular filling and diastolic pressurevolume in conscious dogs. Circulation Research, 24, 269-283.

Snell, R. E., and Luchsinger, P. C. (1965). Determination of the external work and power of the left ventricle in intact man. American Heart fournal, 69, 529-537.

Sparling, C. N., Mook, G. A., Nieveen, J., Vanderslikke, J. B., and Zizlstra, W. C. (1960). Calibration of dye dilution curves for calculating cardiac output and central blood volume. In 3rd European Congress of Cardiology. International Congress Series no. 30, p. 595. Excerpta Medica, Amsterdam.

Waagstein, F., Hjalmarson, A., Varnauskas, E., and Wallentin, I. (1975). Effect of chronic beta-adrenergic receptor blockade in congestive cardiomyopathy. British Heart fournal, 37, 1022-1036.

Requests for reprints to Dr Hamid Ikram, Department of Cardiology, The Princess Margaret Hospital, Cashmere Road, Christchurch 2, New Zealand. 